Pesq. Vet. Bras. 35(6):491-496, junho 2015 DOI: $10.1590 / \mathrm{S} 0100-736 \mathrm{X} 2015000600001$

\title{
Recovery of Mollicutes from the reproductive tract of dairy cattle in the state of Pernambuco, Brazil ${ }^{1}$
}

\author{
Sandra B. Santos ${ }^{2 *}$, José W. Pinheiro-Júnior ${ }^{3}$, André R. Mota² ${ }^{2}$ André S. Santos², Bruno H.L.S. \\ Alves $^{2}$, Júnior M.B. Oliveira ${ }^{3}$, Leonildo B.G. Silva ${ }^{2}$ and Rinaldo A. Mota ${ }^{2}$
}

\begin{abstract}
Santos S.B., Pinheiro-Júnior J.W., Mota A.R., Santos A.S., Alves B.H.L.S., Oliveira J.M.B., Silva L.B.G. \& Mota R.A. 2015. Recovery of Mollicutes from the reproductive tract of dairy cattle in the state of Pernambuco, Brazil. Pesquisa Veterinária Brasileira 35(6):491-496. Laboratório de Bacterioses dos Animais Domésticos, Departamento de Medicina Veterinária, Universidade Federal Rural de Pernambuco, Av. Dom Manoel de Medeiros s/n, Recife, PE 52171-900, Brazil. E-mail: sanbsantos@gmail.com

The aim of the present study was to report the occurrence of members of the Mollicutes class in the reproductive system of dairy cattle in Brazil. Five farms containing dairy cattle were visited in January of 2012. In total, 100 cows of different ages, breeds and stages of lactation were examined in the present study. The cows were part of intensive or semi-intensive management systems and were submitted to mechanical milking or hand milking. The samples were collected after washing the vulvar region with water and soap, and then drying it with paper towels and disinfecting the area with alcohol $\left(70^{\circ} \mathrm{GL}\right)$. Vaginal mucous was collected using a sterile alginate cotton swab, which was rubbed on the vagina, as well as the lateral and internal walls. Vulvovaginal mucous samples were cultured in both liquid and solid modified Hayflick's medium, for mycoplasmas, and UB medium, for ureaplasmas. The PCR assays for Mollicutes and Ureaplasma spp. were performed according to the standard protocols described in the current literature. During isolation, the frequency of Mycoplasma spp. was of 13.0\% (13/100) and for Ureaplasma spp. was of 6.0\% (6/100). In the PCR assays the frequency of Mollicutes was of $26.0 \%$ (26/100) and for Ureaplasma spp. was of $13.0 \%(13 / 100)$ in the dairy cattle studied. This is the first report of these agents in reproductive system of bovine of the Pernambuco state. Further studies are necessary to determine the pathogenic potential and species of these field isolates.
\end{abstract}

INDEX TERMS: Reproduction diseases, mycoplasmosis, dairy cows, vaginal mucous, Ureaplasma spp.

RESUMO.- [Recuperação de Mollicutes do trato reprodutivo de bovinos leiteiros no Estado de Pernambuco.] 0 presente estudo relata a ocorrência de membros da Classe Mollicutes no sistema reprodutivo de bovinos leiteiros no Brasil. Foram visitadas em janeiros de 2012 cinco fazendas de bovinos leiteiros. Um total de 100 vacas de diferentes idades, raças e estágios de lactação foram examinadas. Os animais foram mantidos em sistema de manejo inten-

\footnotetext{
${ }^{1}$ Received on January 17, 2015.

Accepted for publication on May 6, 2015.

${ }^{2}$ Laboratório de Bacterioses dos Animais Domésticos, Departamento de Medicina Veterinária, Universidade Federal Rural de Pernambuco (UFRPE), Av. Dom Manoel de Medeiros s/n, Recife, PE 52171-900, Brazil. *Corresponding author: sanbsantos@gmail.com

${ }^{3}$ Unidade Acadêmica de Garanhuns, UFRPE, Av. Bom Pastor s/n, Boa Vista, Garanhuns, PE 55292-270, Brazil.
}

sivo e/ou semi-intensivo, sendo submetidos aos sistemas de ordenha manual ou mecânica. As amostras de muco foram colhidas após a lavagem da região vulvar com água e sabão, com posterior desinfecção com álcool $\left(70^{\circ} \mathrm{GL}\right)$. 0 muco vaginal foi colhido com suabe alginado estéril que foi friccionado nas paredes internas da vagina. Em seguida, as amostras foram cultivadas em meio Hayflick's modificado, para micoplasmas, e em meio UB, para ureaplasmas, ambos caldo e placa. Os ensaios da PCR para Mollicutes e Ureaplasma spp. foram realizados de acordo com protocolo padrão descrito na literatura. No isolamento, a frequência de Mycoplasma spp. foi de 13\% (13/100) e para Ureaplasma spp. foi de $6 \%(6 / 100)$. Nas reações da PCR a frequência para Mollicutes foi de 26\% (26/100) e para Ureaplasmas spp. foi de 13\% (13/100) nos rebanhos bovinos leiteiros estudados. Este é o primeiro relato destes agentes no trato 
reprodutivo de bovinos no Estado de Pernambuco. Estudos adicionais são necessários para determinar as espécies e o potencial patogênico destes isolados de campo.

TERMOS DE INDEXAÇÃO: Doenças da reprodução, micoplasmoses, vacas leiteiras, muco vaginal, Ureaplasma spp.

\section{INTRODUCTION}

Mollicutes are bacteria that differ from other prokaryotes due to the lack of a cell wall and their genome size, which is the smallest reported (Herrmann 1992, Dybvig \& Voelker 1996). These bacteria inflict a wide range of diseases on livestock and are generally associated with clinical manifestations such as pneumonia, conjunctivitis, polyarthritis, mastitis, agalactia, abortion and infertility (Nicholas 2002, McAuliffe et al. 2005). In cattle, the species of most relevance are in the group known as the Mycoplasma mycoides Cluster (MMC): M. mycoides subsp. mycoides Small Colony (MmmSC); the agent of contagious bovine pleuropneumonia (CBPP); and other mycoplasmas species such as $\mathrm{Myco-}$ plasma bovis, Mycoplasma canadense, Mycoplasma arginini, Mycoplasma alkalescens, Mycoplasma bovirhinis, Mycoplasma bovigenitalium, Mycoplasma conjunctivae, M. mycoides mycoides capri, as well as Ureaplasma diversum and Acholeplasma laidlawaii (Landford 1975, Mulira et al. 1992, Razin et al. 1998, Frey 2002, Tenk 2005, Buzinhani et al. 2007, Marques et al. 2009, Santos et al. 2009). Some of these species are pathogenic, whereas others are considered ubiquitous of the normal flora in the mammary gland, as well as the respiratory and reproductive tracts (Whitford et al. 1994, Razin et al. 1998).

Mycoplasma spp. has often been associated with arthritis, pneumonia and otitis in neonatal calves (Yeruham et al. 1999, Gagea et al. 2006). M. bovis is one of the most economically important species of Mycoplasma in cattle herds, causing outbreaks of otitis, pneumonia and arthritis in calves, as well as highly infectious mastitis in cattle (Ghadersohi et al. 1999, Yeruham et al. 1999, Maeda et al. 2003, Francoz et al. 2004, Lamm et al. 2004, Radaelli et al. 2011). Economic losses caused by the syndrome (otitis-pneumonia-arthritis) in calves, as well as mastitis-agalactia in dairy cattle, have been previously studied in the Europe, United Kingdom, USA and Canada (Jasper 1981, Woldehiwet et al. 1990, Walz et al. 1997, Tenk 2005, Foster et al. 2007, Maunsell \& Donovan 2009) and in the Brazil (Mettifogo et al. 1996, Pretto et al. 2001, Nascimento et al. 2005). M. bovirhinis and M. alkalescens have also been isolated from cattle with mastitis (Jasper 1979, Jasper et al. 1979, Jasper 1981). Infected milk has been the source of Mycoplasma spp. in calves causing otitis and pneumonia. This agent is more prevalent in calves from herds with Mycoplasma mastitis than in calves from herds without Mycoplasma mastitis, and is considered a risk factor for outbreak infections in suckling calves (Jasper et al. 1979, Pfutzner 1990, Lamm et al. 2004).

Ureaplasma diversum colonizes the urogenital region, where the infection has been associated with different clinical manifestations. In cattle, the main disorders are vulvitis, granular vulvovaginitis, endometritis, salpingitis, placentitis, fetal alveolitis, abortions and the birth of weak calves. In bulls, the main disorders are the presence of seminal vesiculitis, epididymitis, balanoposthitis and alterations in spermatozoids (Panangala et al. 1981, Miller et al. 1983, Ruhnke et al. 1984, Pilaszek \& Truszczyn Ski 1988, Cardoso et al. 2000, Nascimento et al. 2005, Oliveira Filho et al. 2005, Buzinhani et al. 2007, Rizzo et al. 2011). The agent is transmitted through organic secretions (semen, preputial and vaginal mucus) and direct contact during sexual intercourse, artificial insemination or embryo transfer (Kirkbride 1987, Hasso et al. 1993, Marques et al. 2009). In addition to reproductive diseases, Ureaplasma spp. has been reported in cases of destructive polyarthropathy (fetus) and mastitis in cattle, although these cases are rare (Himsworth et al. 2009). The aim of the present study was to describe the occurrence of agents of the Mollicutes Class in dairy cattle from different geographical areas in northeastern Brazil.

\section{MATERIALS AND METHODS}

Geographic area. Five dairy cattle farms in the meso-region of the Agreste in the state of Pernambuco were visited in January of 2012. This geographical area is notable in the northeast of the country for its high milk production. The farms investigated were chosen at random in different cities, according to the following geographic coordinates: Garanhuns, municipal districts (Garanhuns: L 0773162 and UTM 9019050; Jupi: L 0565436 and UTM 9056244; Jurema: L 0813401 and UTM 9033624), Vale do Ipanema (Águas Belas: L 0716507 and UTM 8990870) Vale do Ipojuca (Alagoinha: L 0739156 and UTM 9059012), giving a total of five municipal districts (Fig.1).

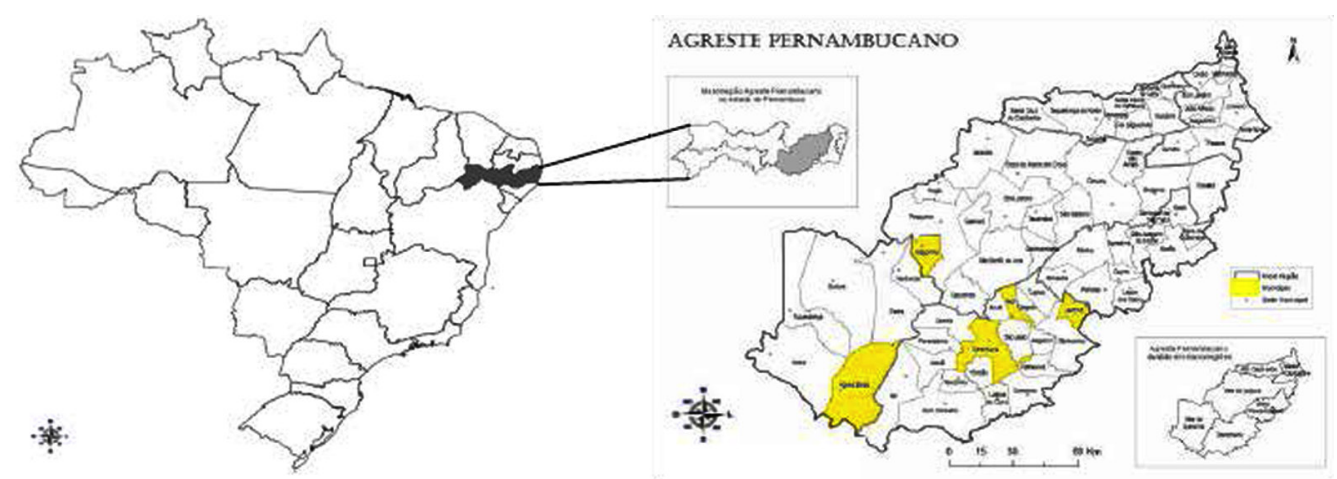

Fig.1. Geographic area of the investigation for the presence of Mollicutes in dairy cattle in Brazil. 
Cows and sampling reproductive tract. In total, 100 cattle of different ages, breeds and stages of lactation were examined in the present study. The cattle were part of intensive or semi-intensive management systems and were submitted to mechanical milking or hand milking. The sampling was performed using a stratified sampling farm, as described by Pereira (2003). Twenty, $15,30,23$ and 20 cattle were randomly chosen from farms A, B, C, $\mathrm{D}$ and $\mathrm{E}$, respectively.

The cattle were examined post milking. The vulvar and vaginal region of each animal was inspected for the presence of mucopurulent and purulent vaginal secretions or lesions. The medical history of the cattle herd was investigated for detected reproductive failure, endometritis, repeat breeding, infertility, the birth of weak calves and abortions. The samples were collected after washing the vulvar region with water and soap, and then drying it with paper towels and disinfecting the area with alcohol $\left(70^{\circ} \mathrm{GL}\right)$. Vaginal mucous was collected using a sterile alginate cotton swab, which was rubbed on the vagina, as well as the lateral and internal walls. The samples were collected in sterile vials which were labeled with the number of the animal and farm. The samples were dipped into transport solution (phosphate buffered saline, pH 7.2), maintained at $4^{\circ} \mathrm{C}$ in a cooler with ice and taken to the Laboratory of Infectious Diseases (LDIC-DMV/UFRPE).

Bacteriological procedures. The vulvovaginal mucous samples were cultured for mycoplamas and ureaplasmas, as described by Razin \& Tully (1996) and Ruhnke \& Rosendal (1994). Previously, $2 \mathrm{~mL}$ of each sample were filtered through a sterile syringe holder coupled with a millipore membrane $(0.45 \mu \mathrm{m}$ diameter). Then, $100 \mu \mathrm{L}$ of the filtrate was diluted up to $10^{-1}$ at $10^{-5}$ and inoculated in both liquid and solid modified Hayflick's medium, that optimizes the isolation of Mycoplasma classic and UB medium, selective for the propagation of ureaplasmas. Subsequently, all samples sowed were incubated at $37^{\circ} \mathrm{C}$ for a minimum period of up to 21 days. The plates were placed in a jar to determine the microaerophilic conditions. The agar plates were checked daily for the presence of colonies using a stereomicroscope (40X). Blind sub cultures were used for up to 60 days, before disposal of the samples. Mollicutes isolates were confirmed by Dienes probe; Mycoplasma genera was used a digitonin sensitivity test and Ureaplasma spp. colonies were identified by the urease production in the U4 medium and their characteristic colony morphology (Whitford et al. 1994).

DNA extraction and PCR assays. The DNA was extracted from the samples by the method described in the commercially available kit (DNA Easy Blood and Tissues Kit ${ }^{\circledR}$, Qiagen Biotechnology, guideline page 25). The primers (GPO-3 and MGSO) that amplify the V6 and V7 conserved regions of the 16S RNA gene, specific to Mollicutes class was used as a procedure for screening of field samples (Van Kuppeveld et al. 1992). The samples were also submitted a PCR assays to detect Ureaplasma spp. using primers UGP-F' (gene location 257-256) and UGP-R' (gene location 862-881) conserved regions of the 16S RNA gene for Ureaplasma spp. (Lauerman 1998). The PCR assays for Mollicutes were performed in a mixture prepared with a volume of $25 \mu \mathrm{L}$, containing $5 \mu \mathrm{L}$ of DNA template, $30 \mathrm{pmol}$ of each primer, $\mathrm{MgCl}_{2}$ $(1.5 \mathrm{mM})$, buffer [ $10 \mathrm{mM}$ of Tris-HCl, $\mathrm{pH} 8.3)$, a mix of deoxynucleoside triphosphate $(50 \mu \mathrm{M})$, Taq DNA Polymerase $(2.5 \mathrm{U})$ and Milli-Q ultrapure water. For Ureaplasma spp., PCR assays were performed with primers at 30pmol, Milli-Q ultrapure water and $6.25 \mu \mathrm{L}$ of TopTaq Mastermix, following the manufacturer's instructions. In vitro amplifications were performed using thermo cycler model PTC-100 (MJ-Research ${ }^{\circledR}$ ). Ultrapure water was used as a negative control. Mycoplasma mycoides mycoides (ref- erence strain GM12) and Ureaplasma diversum (reference strain GMU132, Vup6) were used as positive controls in each reaction, respectively. The amplified PCR was visualized by electrophoresis in $1.5 \%$ agarose gel with $100 \mathrm{bp}$ molecular weight marker, colored with Bluegreen, viewed under ultraviolet light and photodocumented.

\section{RESULTS}

On the farms studied, the cattle examined were asymptomatic for mycoplasmosis and other reproductive disorders during the period of the research. In the swabs from their reproductive systems, the total prevalence for Mollicutes was $19.0 \%(19 / 100)$ in the isolation and $39.0 \%(39 / 100)$ in the PCR. In the samples cultivated in agar Hayflick's medium, $13.0 \%$ growth was recorded and it was possible to visualize flask-shaped cells, which in the digitonin test was confirmed as Mycoplasma spp. In the agar UB medium, $6.0 \%$ of the samples exhibited characteristics of Ureaplasma spp. typical colonial morphology of brown gold colonies, confirmed by urease test. The subculture was made for growth confirmation of Mycoplasma spp. and Ureaplasma spp. The PCR confirmed $26.0 \%$ for Mollicutes the amplicon obtained was of $270 \mathrm{bp}$ and $13.0 \%$ for Ureaplasma spp. with amplicon of $644 \mathrm{bp}$ (Fig.2).

\section{DISCUSSION}

Mycoplasmas are ubiquitous in nature and frequently contain microbiota from different systems, such as the ear, eye, joints and mammary gland, as well as the respiratory and genitourinary tract in animals, humans and insects (Baseman \& Tully 1997, Dybvig \& Voelker 1996). The findings of the present study confirmed that Mycoplasma spp. e Ureaplasma spp. strains grew on both solid and liquid media and were confirmed at the genera level by the PCR. The presence of $U$. diversum in the reproductive tract of cattle

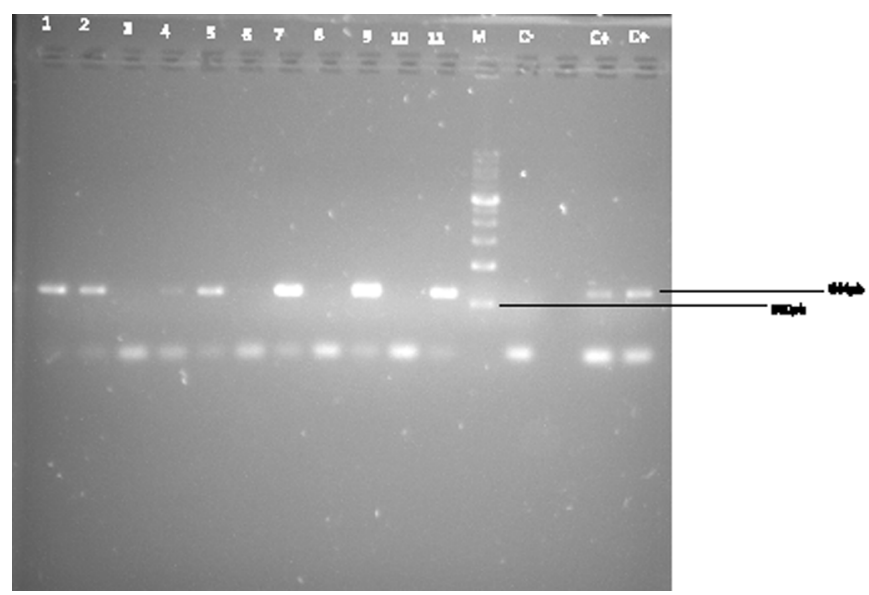

Fig.2. Results of the PCR for Ureaplasma spp. in the vaginal mucous of dairy cows, state of Pernambuco, Brazil. Lane M, molecular size marker $\left(\right.$ Amresco $^{\circledR} 1 \mathrm{~kb}$, amplisize standard 500 10,000); Lanes 1,2,4,5,7,9,11 DNA Ureaplasma spp.; Lane (C-), negative control; Lanes $(\mathrm{C}+)$ Positive control. 
with or without symptoms of mycoplasmosis has been reported in the literature by several authors (Oliveira Filho et al. 2005, Buzinhani et al. 2007, Razin et al. 1998). These agents in the reproductive tract of cattle may or may not be associated with outbreaks of reproductive disorders. However, the genus Ureaplasma spp. has often been associated with disease outbreaks (Albertsen 1955, Onoviran et al. 1975, Britton et al. 1987, Le Grand et al. 1995, Cardoso et al. 1997, Nascimento et al. 1998, Cardoso et al. 2000, Cardoso \& Vasconcellos 2004, Nascimento et al. 2005). In cattle, it can cause placentitis, fetal alveolitis, granular vulvovaginitis, abortion and the birth of weak calves and infection. In bulls, it may result in seminal vesiculitis, balanoposthitis and alterations in spermatozoids (Howard et al. 1976, Mulira \& Saunder 1994, Himsworth et al. 2009, Marques et al. 2009). The occurrence of Ureaplasma spp. in cattle could be a potential risk for manifestations of reproductive diseases that have already been reported in the literature. The possible transmission route is through direct contact during sexual intercourse or by artificial insemination. This bacteria is shed in semen, milk, preputial and vaginal mucus (Kirkbride 1987, Britton et al. 1988, Cardoso \& Vasconcellos 2004).

In Brazil, there are very few studies reporting Ureaplasma infection in cattle herds. However, Nascimento et al. (1998) isolated M. bovirhinis in the vaginal mucus of heifers, highlighting the importance of this species as a cause of reproductive failure in this country, as well as a probable decrease in milk and meat production, similar to what occurs in others countries. M. bovis was diagnosed in $57 \%$ of the samples of vaginal mucus from cattle with reproductive disorders (vulvovaginitis, abortion, stillborn) and the authors highlighted the risk of venereal transmission of Mycoplasma spp. (Nascimento et al. 2005). In the northeast of Brazil, Santos et al. (2013) reported Mollicutes with frequencies of $65.6 \%$ and for Ureaplasma diversum of $15.6 \%$ in reproductive disease outbreak in cattle in Paraíba, the cows presented heat repetition, granular vulvovaginitis and abortions.

In the present study, the occurrence of Mycoplasma and Ureaplasma spp. in the vaginal mucus was low in comparison to the frequencies reported in other Brazilian states (Cardoso et al. 1997, Cardoso et al. 2000, Cardoso \& Vasconcelos 2004, Buzinhani et al. 2007, Santos et al. 2013). However, it was possible to prove the viability of these microorganisms through bacterial isolation, thus highlighting the possibility of these agents causing reproductive diseases in these cattle during opportunistic outbreaks. Further studies are required to prove the species and pathogenicity of these isolates. In the cattle assessed in the present study, there was no history of reproductive disorders or abortion, although the presence of these agents in the vaginal mucus of cows could be considered a risk factor for reproductive disease.

\section{CONCLUSION}

It was possible to verify the occurrence of Mycoplasma spp. and Ureaplasma spp. in dairy cattle from different geographical areas of the state of Pernambuco. This is the first report of these bacteria in this region of Brazil. Further studies are necessary to determine the species and pathogenic potential of these field isolates.

Acknowledgements.- This study was supported by the Conselho Nacional de Desenvolvimento Científico e Tecnológico - CNPq (MCT/ CNPq) and Fundação de Amparo à Ciência e Tecnologia do Estado de Pernambuco - FACEPE (Programa de Desenvolvimento Científico Regional - DCR no 0006-5.05/10 and APQ 1512-5.05/10). To Dr. Elmiro Rosendo do Nascimento by providing standards strains used on the project.

Conflicts of interest.- The authors have no conflicts of interest to declare.

Research Ethics Committee.- This project was approved by the ethics committee of the UFRPE/DMV Process no 23082.004146/2011-28.

\section{REFERENCES}

Albertsen B.E. 1955. Pleuropneumonia-Like organisms in the semen of Danish artificial insemination bulls. Nordish Veterinaer Medicin 7:169201.

Baseman J.B. \& Tully J.G. 1997. Mycoplasmas: sophisticated, reemerging, and burdened by their notoriety. Emerg. Infect. Dis. 3:21-32.

Britton A.P., Ruhnke H.L., Miller R.B., Johnson W.H., Leslie K.E. \& Rosedal S. 1987. In vitro exposure of bovine morulae to Ureaplasma diversum. Can. J. Vet. Res. 51:198-203.

Britton A.P., Miller R.B., Ruhnke H.L. \& Johnson W.H. 1988. The recovery of ureaplasmas from bovine embryos following in vitro exposure and ten washes. Theriogenology 30:997-1003.

Buzinhani M., Metiffogo E. \& Timenetsky J. 2007. Detecção de Mycoplasma spp. e Ureaplasma diversum em vacas com distúrbios reprodutivos. Arq. Bras. Med. Vet. Zootec. 59:1368-1375.

Cardoso M.V. \& Vasconcelos S.A. 2004. Importância das micoplasmoses na infertilidade de touros. Arqs Inst. Biológico, São Paulo, 71:257265.

Cardoso M.V., Scarcelli E., Grasso L.M.P.S., Teixeira S.R. \& Genovez M.E. 2000. Ureaplasma diversum and reproductive disorder in Brazilian cows and heifers, first report. Anim. Reprod. Sci. 63:137-143.

Cardoso M.V., Grasso L., Stefano E., Okuda L.H. \& Cunha R.A.F. 1997. Isolamento de Ureaplasma diversum e Mycoplasma spp. em casos de Vulvite Granular Bovina. Revta Bras. Reprod. Anim. 21:172-173.

Dybvig K. \& Voelker L.L. 1996. Molecular biology of mycoplasmas. Annu. Rev. Microbiol. 50:25-57.

Foster A.P., Naylor R.D., Howie N.M., Nicholas R.A.J. \& Ayling R.D. 2007. Mycoplasma bovis and otitis in dairy calves in the United Kingdom. Vet. J. 179:455-457.

Francoz D., Fecteau G., Desrochers A. \& Fortin M. 2004. Otite media in dairy calves: A retrospective study of 15 cases (1987 to 2002). Can. Vet. J. 45:661-666.

Frey J. 2002. Mycoplasmas of animals, p.73-90. In: Razin S. \& Herrmann R. (Eds), Molecular Biology and Pathogenicity of Mycoplasmas. Kluwer Academic, New York.

Gagea M.I., Bateman K.G., Shanahan R.A., Van Dreumel T., McEwen B.J.S., Archambault M. \& Caswell J.L. 2006. Naturally occurring Mycoplasma bovis-associated pneumonia and polyarthritis in feedlot beef calves. J. Vet. Diagn. Invest. 18:29-40.

Ghadersohi A., Hirst R.G., Forbes-Faulkener J. \& Coelen R.J. 1999. Preliminary studies on the prevalence of Mycoplasma bovis mastitis in dairy cattle in Australia. Vet. Microbiol. 65:185-194. 
Hasso S.A., AI-Aubaidi J.M. \& Al-Darraji A.M. 1993. Contagious agalactia in goats: it's severity as related to the route of infection and pregnancy. Small Rumin. Res. 10:263-275.

Herrmann R. 1992. Genome Structure and Organization, p.157-68. In: Maniloff J., McElhaney R.N., Finch L.R. \& Baseman J.B. (Eds), Mycoplasmas: molecular biology and pathogenesis. Am. Soc. Microbiol., Washington, DC.

Himsworth C.G., Hill J.E., Huang Y., Waters E.H. \& Wobeser G.A. 2009. Destructive polyarthropathy in aborted bovine fetuses: a possible association with Ureaplasma diversum Infection? Vet. Pathol. 46:269272.

Howard C.J., Gourlay R.N., Thomas L.H. \& Stott E.J. 1976. Induction of pneumonia in gnotobiotic calves following inoculation of Mycoplasma disparand ureaplasmas (T-mycoplasmas). Res. Vet. Sci. 21:227-231.

Jasper D. 1979. Bovine mycoplasmal mastitis. J. Am. Vet. Med. Assoc. 175: 1072-1074.

Jasper D. 1981. Bovine mycoplasmal mastitis. Adv. Vet. Sci. Comp. Med. 25:121-159.

Jasper D., Dellinger J. \& Rollins M. 1979. Prevalence of Mycoplasma bovine mastitis in California. Am. J. Vet. Res. 40:1043-1047.

Kirkbride C.A. 1987. Mycoplasma, Ureaplasma, and Acholeplasma infections of bovine genitalia. Vet. Clin. North Am., Food Anim. Pract. 3:575591.

Lamm C.G., Munson L., Thurmond M.C., Barr B.C. \& George L.W. 2004. Mycoplasma otites in California calves. J. Vet. Diagn. Invest. 16:397402.

Landford E.V. 1975. Mycoplasma species recovered from the reproductive tracts of Western Canadian cows. Can. J. Comp. Med. 39:133-137.

Lauerman L.H. 1998. Mycoplasma PCR assays, p.41-42. In: Lauerman L.H. (Ed.), Nucleic Acid Amplification Assays for Diagnosis of Animal Diseases. American Association of Veterinary Laboratory Diagnosticians, Turlock, CA.

Le Grand D., Poumarat F. \& Martel J.L. 1995. Genitale infection by Ureaplasma diversum: survey in cattle in France. Vet. Res. 26:11-20.

Maeda T., Shibahara T., Kimura K., Wada Y., Sato K., Imada Y., Ishikawa Y. \& Kadota K. 2003. Mycoplasma bovis associated suppurative otites media and pneumonia in Bull calves. J. Comp. Pathol. 129:100-110.

Marques L.M., Buzinhani M., Lopes Neto R., Oliveira R.C., Yamaguti M., Guimarães A.M. \& Timenetsky J. 2009. Detection of Ureaplasma diversum in bovine semen straws for artificial insemination. Vet. Rec. 165:572-573.

Maunsell F.P. \& Donovan G.A. 2009. Mycoplasma bovis Infections in young calves. Vet. Clin. Food Anim. 25:139-177.

McAuliffe L., Ellis R.J., Lawes J.R., Ayling R.D. \& Nicholas R.A.J. 2005. 16S rDNA PCR and denaturing gradient gel electrophoresis: a single generic test for detecting and differentiating Mycoplasma species. J. Med. Microbiol. 54:731-739.

Mettifogo E., Nascimento E.R., Muller E.E., Nascimento M.G.F. \& Freitas J.C. 1996. Mastite bovina por Mycoplasma bovis. Revta Bras. Med. Vet. 18:2225.

Miller R.B., Ruhnke H.L., Doig P.A., Poitras B.J. \& Palmer N.C. 1983. The effects of Ureaplasma diversum inoculated into the amniotic cavity in cows. Theriogenology 20:367-374.

Mulira G.L. \& Saunders J.R. 1994. Humoral and secretory antibodies to Ureaplasma diversum in heifers following subcutaneous vaccination and vaginal infection. Can. J. Vet. Res. 58:104-108.

Mulira G.L., Saunders R.J. \& Barth D.A. 1992. Isolation of Ureaplasma diversum and mycoplasma from genital tracts of beef and dairy cattle in Saskatchewan. Can. Vet. J. 33:46-49.
Nascimento M.G.F., D’Angelis F.H.F., Nascimento E.R., Resende O.A. \& Lignon G.B. 1998. Mycoplasma bovirhinis em muco vaginal de novilhas. Revta Bras. Med. Vet. 20:210-214.

Nascimento M.G.F., D’Angelis F.H.F., Nascimento E.R. \& Resende O.A. 2005. Envolvimento de micoplasmas em vacas com distúrbios reprodutivos. Acta Scient. Vet. 33:195-199.

Nicholas R.A.J. 2002. Improvements in the diagnosis and control of diseases of small ruminants caused by mycoplasmas. Small Rumin. Res. 45:145-149.

Oliveira Filho B.D., Porto R.N.G., Gambarini M.L., Kunz T.L., Ferraz H.T., Viu M.A.O., Lopes D.T. \& Sousa A.P.F. 2005. Isolamento de Ureaplasma diversum em muco vulvovaginnal de vacas leiteiras repetidoras de estro no Estado de Alagoas, Brasil. Arch. Vet. Sci. 10:151-156.

Onoviran O., Truscott R.B., Fish N.A., Barker C.A.V. \& Ruhnke H.L. 1975. The recovery of mycoplasmas from the genital tracts of bulls in artificial breeding units in Ontario. Can. J. Comp. Med. 39:474-475.

Panangala V.S., Winter A.J., Wijesinha A. \& Foote R.H. 1981. Decreased motility of bull spermatozoa caused by Mycoplasma bovigenitalium. Am. J. Vet. Res. 42:2090-2093.

Pereira M.G. 2003. Epidemiologia Teoria e Prática. 7th ed. Guanabara Koogan, Rio de Janeiro. 596p.

Pfutzner H. 1990. Epizootiology of the Mycoplasma bovis infection of cattle. Zentralbl. Bakteriol. 20(Suppl.):394-399.

Pilaszek J. \& Truszczyn Ski M. 1988. Affinity of microorganisms of the genus Ureaplasma to the reproductive organs of cattle. Comp. Immunol. Microbiol. 11:177-180.

Pretto L.G., Muller E.E., Freitas J.C., Mettifogo E., Buzihani M., Yamaguti M. \& Salvador R. 2001. Mastite bovina por Mycoplasma bovis em rebanhos leiteiros. Pesq. Vet. Bras. 21:143-145.

Radaelli E., Castiglioni V., Losa M., Benedetti V., Piccinini R., Nicholas R.A.J., Scanziani E. \& Luini M. 2011. Outbreak of bovine clinical mastitis caused by Mycoplasma bovis in a North Italian herd. Res. Vet. Sci. 91:251-253.

Razin S. \& Tully J.G. 1996. Molecular and Dagnostic Procedures in Mycoplasmology. 2nd ed. Academic Press, Califórnia. 463p.

Razin S., Yogev D. \& Naot Y. 1998. Molecular biology and pathogenicity of mycoplasmas. Microbiol. Mol. Biol. Res. 62:1094-1156.

Rizzo H., Meira Junior E.B.S., Oliveira R.C., Yamaguti M., Buzinhani M., Timenetsky J. \& Gregory L. 2011. Isolamento e PCR para detecção de Mollicutes em muco vaginal e sua associação com problemas reprodutivos em ovinos criados na região de Piedade, São Paulo, Brasil. Ciência Rural 41:324-329.

Ruhnke H.L. \& Rosendal S. 1994. Useful protocols for diagnosis of animal mycoplasmas, p.141-155. In: Whitford H.W., Rosenbusch R.F. \& Lauerman L. (Eds), Mycoplasmosis in Animals: Laboratory Diagnosis. Iowa State University Press, Ames, IA.

Ruhnke H.L., Palmer N.C., Doig P.A. \& Miller R.B. 1984. Bovine abortion and neonatal death associated with Ureaplasma diversum. Theriogeniology 21:295-301.

Santos S.B., Nascimento E.R., Faccini J.L.H., Barreto M.L. \& Pereira V.L.A. 2009. Potentially pathogenic mycoplasmas in the external ear canal of clinically normal cattle in southeast brazil: first report. Braz. J. Microbiol. 40:455-457.

Santos S.B., Pinheiro-Júnior J.W., Oliveira A.A.F., Mota A.R., Oliveira J.M.B., Veras G.A., Nascimento E.R. \& Mota R.A. 2013. Ocorrência de Mollicutes e Ureaplasma spp. em surto de doença reprodutiva em rebanho bovino no Estado da Paraíba. Pesq. Vet. Bras. 33:315-318.

Tenk M. 2005. Examination of Mycoplasma bovis infection in cattle. Doctoral Thesis, SzentIstván University, Postgraduate School of Veterinary Science, Budapest. 70p. 
Van Kuppeveld F.J.M., Van Der Logt J.T.M., Angulo A.F., Zoest M.J.V., Quint W.G.V., Niesters H.G.M., Galama J.M.D. \& Melchers W.J.G. 1992. Genus and species specific identification of mycoplasmas by $16 \mathrm{~S}$ rRNA amplification. Appl. Environ. Microbiol. 58:2606-2615.

Walz P., Mullaney T. \& Render J.A. 1997. Otitis media in preweaned Holstein dairy calves in Michigan due to Mycoplasma bovis. J. Vet. Diagn. Invest. 9:250-254.

Whitford H.W., Rosenbusch R.F. \& Lauerman L.H. 1994. Mycoplasmosis in
Animals: laboratory diagnosis. lowa State University Press, Ames, IA. $173 p$.

Woldehiwet Z., Mamache B. \& Rowan T.G. 1990. Effects of age, environmental temperature and relative humidity on the colonization of the nose and trachea of calves by Mycoplasma spp. Brit. Vet. J.146:419-424.

Yeruham I., Elad D. \& Liberbol M. 1999. Clinical and microbiological study of an otitis media outbreak in calves in a dairy herd. J. Vet. Med. B 46:145-150. 